\title{
The Relationship among Leadership Commitment, Organizational Performance, and Employee Engagement
}

\author{
Boonyada Nasomboon ${ }^{1}$ \\ ${ }^{1}$ Graduate School of Commerce, Burapha University, Chonburi, Thailand \\ Correspondence: Boonyada Nasomboon, Graduate School of Commerce, Burapha University, Chon Buri \\ Campus 169 Long-Hard Bangsaen Road, Saen Sook Sub-district, Mueang District, Chon Buri Province, 20131. \\ Tel: 66-81-295-2450. E-mail: boonyada_noi@ hotmail.com
}

Received: July 14, 2014

Accepted: August 11, 2014

Online Published: August 25, 2014

doi:10.5539/ibr.v7n9p77

URL: http://dx.doi.org/10.5539/ibr.v7n9p77

\begin{abstract}
The increasingly competitive global economy has pushed companies to exploit their available resources as a ways of achieving competitive advantage. Leadership is critically important because it has a huge impact on the condition of the organization. The purpose of this quantitative study was to investigate the relationship among Leadership Commitment (LSC), Organizational Performance (ONP), and Employee Engagement (EYE) via their effects on a set of mediating variables of Employers Branding (EYB), Strategic Alignment (SGA), Organizational Agility (ONA), and Human Resource Practices (HRM). A conceptual model of these relationships was developed on existing theories. Data were collected from 26 petrochemical companies' managers to be analyzed as identifiers of the latent variables in the model. This process was completed using the principles of structural equation modeling (SEM) which required confirmatory factor analysis on the measurement model and path analysis on the structural model. The analysis finds that Leadership Commitment directly affects Organizational Performance and Employee Engagement. The study also finds that Employers Branding, Strategic Alignment, Organizational Agility, and Human Resource Practices are an intervening factor between Leadership Commitment, Organizational Performance, and Employee Engagement. In addition, Strategic Alignment does not directly relate to human resource practice- it does so indirectly via Employers Branding and Organizational Agility. This result suggests that an increasing behavior of leader who commit to staying with their company, working toward organizations' target success, focusing on achieving goals, and also working toward the success of organizational change, appears to influence the value of organizational performance as well as the engagement levels of employees.
\end{abstract}

Keywords: leadership commitment, organizational performance, employee engagement, path analysis

\section{Introduction}

\subsection{Background}

Leadership is critically important because it affects the condition of the organization. Empirical findings of the most recent research studies have indicated that Organizational Performance, Employee Engagement, Employee Commitment are desired by corporate leaders and management (Kieu, 2010; Babakus et al., 2003). Any organization requires effective leaders who can positively influence their followers by increasing Employee Engagement in order to support business performance. The potential variables associated with leadership behaviors might be significant. According to Kiue (2010), the behaviors of top-level leadership have significant impact on the organization. Studies on the leadership level (e.g. immediate supervisor and top management) have been independently investigated and have been shown to significantly impact employee behaviors (Cascio, Mariadoss, \& Mouri, 2010). Leaders are a vital ingredient in the success of organization. Leaders who are high in task behavior and support behavior have been shown to be particularly effective at promoting engagement (Schaufeli \& Salanova, 2008). Leaders with a high commitment may be the key to the development of an environment that provides organizational effectiveness. Since effective leaders have been demonstrated to be predictive of attitudes and performance in organizations, the question was raised regarding whether other leadership behaviors would also be predictive in the same way or not (Cascio et al., 2010). Studies in the management literature suggest that top management commitment may have an even more powerful impact on organizational practices. Top management commitment has been shown to be the main driver behind employee 
behaviors in the areas of service quality (Babakus et al., 2003). Commitment in the workplace can take various forms and, arguably, have potential to influence organizational effectiveness (Meyer \& Herscovitch, 2001). Commitment to more specific objectives might produce the opposite effect. Efforts might be directed at achieving the specific objective perhaps to the detriment of the higher order goals of the organization as mentioned by Mayer \& Herscovitch, (2001).

Many researchers have also argued for the importance of a closer examination of the role of Employee Engagement. Different HR practices, including job design, recruitment, selection, training, and compensation and performance management can enhance Employee Engagement (Vance, 2006). Employers Branding is a relatively new approach toward recruiting and retaining the best possible human talent within an employment environment that is becoming increasingly competitive. Employee branding has the potential to be a valuable concept of Employers Branding that is to convince employees that their organization is a good place to work -it helps to retain them and convinces them to commit to the organization (Love \& Singh, 2011). Although firms commonly focus their branding efforts toward developing product and corporate brands, branding can also be used in the area of human resource management (Backhaus \& Tikoo, 2004). Researchers argue that human resource system aligned with a firm's strategy can be the source of competitive advantage for the firm (Stringer, 2007). Organizations may be able to foster Employee Engagement through Strategic Alignment of their organizations (Stringer, 2007). In a well-alignment organization, all efforts are traceable to the high-level goals. Agility is the essential factor obtained for responding and reacting to the changes that is the reaction to the challenges of a work environment occurred through changes and uncertainties. The problem is that how any organization can successfully deal with unpredictable, dynamic, and academia for a few decades (Sherehiy et al., 2007). According to McCann et al. (2009), Organizational Agility has significant positive correlations with Organizational Performance. Organizational Agility in the research framework is good in current business environment than is changing and uncertain. Successful company must, therefore, acquire the capability to achieve and explore the competitive advantage in synergy. Companies which are exhibiting higher levels of agility are more competitive and more profitable.

The problem is that the commitment behavior used by leaders appears to influence the value of organizational performance as well as the level of employee engagement within the organization through the series of mediation.

\subsection{The Purpose of the Study and Question}

The purpose of this study was to investigate the relationship among Leadership Commitment, Operational Performance, and Employee Engagement via their effects on a set of mediating variables: Employers Branding, Strategic Alignment, Organizational Agility and Human Resource Practices. It seeks to find answers to the following: Does leadership commitment influence organizational performance and the level of employee engagement? This research was conducted in Map Ta Phut, Thailand and particularly emphasized the petrochemical industry. These industrial sectors include large companies with high workforce diversity. Their organizational structures gather together many knowledgeable employees with intensive skills and expertise. Therefore, companies in these industrial sectors are appropriate for this study.

\subsection{Significance of the Study}

The goal of this study was intended to contribute to the body of literature on behaviors of leaders, Employee Engagement, and Organizational Performance. This objective is important because the results of this study can help leaders to recognize their commitment and to understand if their commitment has an effect on the level of Employee Engagement and Organizational Performance. This study is significant because it is the first study to empirically examine Leadership Commitment and their effects on Employee Engagement and Organizational Performance via their effects on a set of mediating variables, Employers Branding and Strategic Alignment and Organizational Agility, and Human Resource Practices.

\section{Literature Review and Theoretical Framework}

Leadership behavior defined leadership as an influence relationship among leaders and followers who intend real changes and outcomes that reflect their shared purposes. Over the course of time, a number of dimensions or facets of leadership behavior have been developed and applied as researchers continue to discover what contribution to leadership success and failures. Past research on leadership behavior of directive, supportive and participative found the relationship on commitment (Yiing et al., 2008). Kieu (2010) found strong correlation between transformation and transactional leadership on year-over-year revenue growth and profits. Any organization requires effective leaders who can positively influence their employees by increasing engagement that supports business performance. Block and Manning (2007) discussed the core elements needed to build an 
effective leadership development in order to enhance organizational success. This approach consists of six steps: (1) identification of leadership needs, (2) identified knowledge and skill gaps, (3) created for engagement, (4) workplace supports to ensure that the developing leader is receiving ongoing guidance and quality feedback, (5) recognition leader's commitment and contribution to the organization, and (6) aligned with the strategic goals of the organization. Amagoh (2009) argues that the institutionalization of a comprehensive leadership development program in the fabric of an organizational culture is essential to ensure leadership effectiveness and high organizational performance. Organizations should take a long-term approach to leadership development and create a supportive environment in order to produce effective leaders. The approach to leadership development may be used commitment framework to examine and evaluate leadership commitment. It may also be used to identify specific events that have led to successful organizational achievements Amagoh (2009).

Commitment in the workplace has the potential to influence organizational effectiveness and employee well-being. Commitment has been defined and measured in many different ways. Even if we acknowledge the existence of multiple dimensions, or forms, of commitment, however, there has to be a core essence that characterizes the construct and distinguishers it from other constructs (Mayer \& Herscovitch, 2001). They look more carefully at the implications of the different commitment mind-sets on behavior and develop mechanisms involved the three mind-sets (affective, continuance and normative commitment). They mentioned that affective commitment should be related to a wider range of behaviors than other forms of commitment even under conditions in which the focal behavior is clearly specified in the measure. The objective of commitment research should specify the focal behavior and target of interest. To illustrate how the focal behavior can be varied depending on the interests of the investigator, therefore, two different versions of a measure of "organization commitment" one focusing on membership and one on the attainment of organizational goal (Mayer \& Herscovitch, 2001). Several studies within the organizational commitment literature have demonstrated associated behavioral outcomes with commitment (Meyer et al., 2001; Yiing, 2014).

Therefore, Leaders who are commitments to general targets with broadly defined focal behavior (e.g. staying with their company, working toward organizations' target success, focusing on achieving goals, and also working toward the success of organizational) may influence organizational performance as well as impact on the level of employee engagement.

The theoretical basis of the research model is derived from several sources. The model is developed from a general model of workplace commitment that can reflect varying degrees of desire, perceived cost and obligation (Mayer \& Herscovitch, 2001). The overall research question in this study sought to answer: "Does Leadership Commitment influence Organizational Performance and Employee Engagement?" To examine this research questions, causal model approach was developed (see Figure.1), representing a series of hypotheses how Leadership Commitment might influence Organizational Performance and Employee Engagement via their effects on a set of mediating variables. The following research hypotheses were examined in this study based on the objectives and the existing literature.

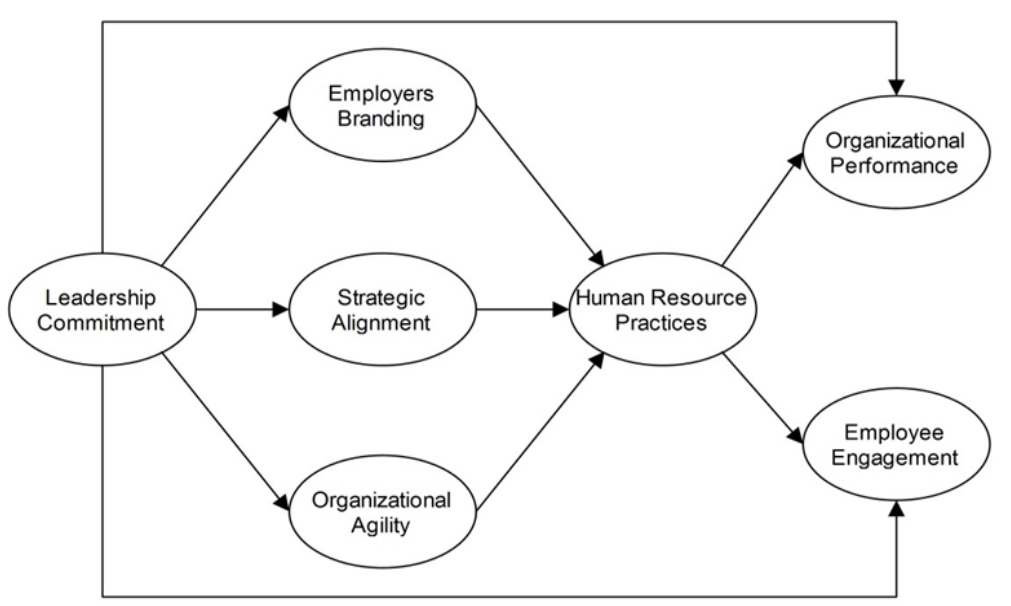

Figure 1. Research model 
From a research of the literature, it was found that $\mathrm{H} 1, \mathrm{H} 4, \mathrm{H} 7, \mathrm{H} 8, \mathrm{H} 9$, and $\mathrm{H} 10$ are supported by considerable empirical evidence. However, H2, H3, H5, and H6 appear intuitively obvious, but have been subjected to limited empirical analysis. This section also contains a more detailed justification of each hypothesis.

\section{Leadership Commitment on Employers Branding}

Commitment of leadership is critically important to the outcome (Yiing et al., 2008; Kieu, 2010). Employers Branding concerned with building an image in the minds of the potential labor market that it creates an image that makes people want to work for the firm because of its well-managed firm Vallaster \& Chermatony, (2005). Thus, the behavioral characteristics of leaders as a committed individual may predict the employers branding.

Hypotheses 1: Leadership Commitment has a positive direct effect on Employers Branding.

\section{Leadership Commitment on Strategic Alignment}

Preliminary research has found that white-collar employees who understand their organization's strategy and their corresponding strategically aligned job behaviors have higher performance and employer-desired work attitudes, such as job satisfaction and commitment, versus employees who do not understand their organization's strategies and do not understand corresponding aligned job behaviors (Boswell, 2006). The behavioral characteristics of leaders as a committed individual may affect Strategic Alignment.

Hypotheses 2: Leadership Commitment has a positive direct effect on Strategic Alignment.

\section{Leadership Commitment on Organizational Agility}

The assumption was that certain leadership attributes would be found to be characteristic of more agile organizations. Thus, organization can successfully deal with unpredictable, dynamic, and constantly changing environments. Therefore, leadership attributes may affect more agile organizations.

Hypotheses 3: Leadership Commitment has a positive direct effect on Organizational Agility.

\section{Employers Branding on Human Resource Practices}

The term employer brand appears to have first been used in 1996 and was defined as "the package of functional, economic and psychological benefits provided by employment and identified with the employing company" (Ambler and Barrow, 1996, p.187). Once Employers Branding is initiated, it gained notoriety by improving recruiting effectiveness during the extremely competitive period known as the war for talent. Management scholars can use Employers Branding to integrate in the HR such as recruiting, selection and retention literatures which can be especially valuable in the search for an organizing framework for human resource management as mentioned by Backhaus \& Tikoo (2004). Martin et al., (2005) developed a model to link between HR and employers branding. The best employers have lower voluntary turnover rates Love \& Singh, (2011). Thus, well branding management of employers may affect Human Resource Practices

Hypotheses 4: Employers Branding has a positive direct effect on Human Resource Practices.

\section{Strategic Alignment on Human Resource Practices}

Strategic alignment is when employees understand and are able to enact the organization's strategy. Organizations may be able to foster employee engagement through strategic alignment (Stringer, 2007). Gagnon and Michael (2003) found that employees who increased knowledge of a strategy tend to exhibit increased levels of commitment, job satisfaction, and trust. Boswell (2006) suggests that organizations should perhaps look beyond simply communicating their strategic direction to employees and instead focus on whether employees accurately understand the behaviors that contribute to strategic success. Human resource practices are well positioned to play important role in the alignment process, and they share similar methods. Thus, degree of strategic alignment is associated with Human Resource Practices

Hypotheses 5: Strategic Alignment has a positive direct effect on Human Resource Practices.

\section{Organizational Agility on Human Resource Practices}

Agility is the essential factor to be obtained for responding and reacting to the changes (Sherehiy et al., 2007). The assumption was that the reaction to the challenges of a work environment occurred through changes and uncertainties may affect human resource activities. Despite the differences, "agility is the successful exploration of competitive based (speed, flexibility, innovation proactivity, quality and profitability) through the integration of reconfigurable resources and best practices" (Yusuf et al., 1999). The workforce agility can be achieved via cross-training because cross-trained workers represent flexible capacity since workers can be shifted when they are needed. McCann et al., (2009) have demonstrated that environmental turbulence may indeed be managed by building agility and resiliency. The results have shown that agility and resiliency have significant positive 
correlations with both performance measures. Yauch (2011) has found that the combination of high success and high turbulence is determined to be the only agile company.

Hypotheses 6: Organizational Agility has a positive direct effect on human resource practice.

Human Resource Practices on Organizational Performance

In modern word, HRM is solution of several of the problem which influences the capability of work to provide for individual growth. The outcome of Human Resource Practices on Organizational Performance has been given different perceptions. A comprehensive study of human resources (Huselid, 1995) has found the relationship of 13 human resources management in firms. Thus, a competitive advantage to the understanding of how HR practices (e.g. selection, training, compensation, and appraisal) contribute to firm performance is crucial. Past research found organizations that implement highly selective staffing, extensive training, and performance management practices are likely to have higher performance (Youndt et al., 1996; Moideenkutty et al., 2010; Dimba, 2010). Hence, the set of human resources may affect level of Organizational Performance.

Hypotheses 7: Human Resource Practices have a positive direct effect on Organizational Performance.

Human Resource Practices on Employee Engagement

The concept of engagement began to surface in the organization around two decades ago. Kahn (1990), one of the first scholars to study engagement, defined what the termed personal engagement as the "harnessing of organizational members' selves to their work roles; in engagement, people employ and express themselves physically, cognitively, and emotionally during role performance"(p.694). Strong evidence of the positive relationship between Human Resource Practices and Employee Engagement has been noted (Rana et al., 2014). The employees who are well recognized to Human Resource Practices were also scored highly on Employee Engagement (Wright et al., 2005). Previous study found the significant relationship of human resource practices on employee engagement (Vance, 2006; Dimba, 2010; Sardar et al., 2011).

Hypotheses 8: Human resource practice has a positive direct effect on Employee Engagement.

\section{Leadership Commitment on Organizational Performance and Employee Engagement}

The concept of commitment has been used in a variety of ways. Researchers have written about commitment to organization, occupations, organizational changes and to policy decision (see Mayer \& Herscovitch, 2001, for a comprehensive review). The concept of leadership is also fraught with definitional confusion Zhang et al., (2014). Despite this," leadership" appears to be one of the single biggest factors affecting organizational performance. Therefore, Leaders who are committed may be the key to the development of an environment that provides organizational effectiveness (Cascio et al., 2010). Kieu (2010) found strong correlation between transformation and transactional leadership on year-over-year revenue growth and profits. Munley (2006) has found the level of agreement and commitment of leadership to be critically important in the overall organizational performance.

Hypotheses 9: Leadership Commitment has a positive direct effect on Organizational Performance.

Most organizations understand the importance of engaging and keeping key employees, and they make serious efforts in these areas. Past research found that leadership is the one factor that influences performance Anitha, (2013). Effective leadership has been associated with employee engagement (Zhang et al., 2014).

Hypotheses 10: Leadership Commitment has a positive direct effect on Employee Engagement.

\section{Methodology}

\subsection{Participant}

HR practices have been measured across numerous industries and corporate levels (e.g. Huseld, 1995; Terpstra \& Rozell, 1993). While providing useful information, HR practices cause two potential problems. First, HR practices, technologies, labor pools and determinants of financial performance differ significantly across industries resulting in potential confounds and /or error variance. Second, measurement at this level assumes that every site within the corporation uses the same level of the corporation. A more specific and realistic approach would be to examine the place at where they are implemented: the specific site (Pils \& MacDuffie, 1994). For these reasons, this study chose to focus the study on work sites within a specific industry. The target population in this study was managers working in the petrochemical company in Rayong, Thailand. The scope of this study was confined to petrochemical organizations and employees employed by these organizations. The target employees being recruited were of two groups: the general staff permanently employed and the employees holding the manager position. 


\subsection{Sampling Procedures}

According to Creswell (2005), probability sampling takes place if all of the elements in the population have a chance of being selected. Then, participants in this study were selected by using convenience sampling technique. The procedures for selecting participants included (a) the sampling method (b) the percentage of the sample approached that participated; and (c) the number of participants who selected themselves into the sample. Three criteria concerning the settings and locations in which the data were collected as well as any agreements and payments made to participants were agreements with the institutional review board, ethical standards conformity, and safety monitoring procedures. The data collection process was conducted over a period of 3 months from the first week of May 2013 until the end of July 2013. The introductory letter, the consent forms, and the questionnaires, were put in sealed envelope which was delivered by the researcher to cooperating persons who were asked by the researcher to distribute the questionnaires to the respondents.

\subsection{Sample Size}

Since the study employed SEM as the tool for the hypothesis testing, it based its sample size on the suggested number of 10 to 20 times the number of the indicators in the study (Garson, 2006). Hair et al. (2006), indicate that MLE has been proven fairly robust in regards to violations of the normality assumption and produces reliable results under most circumstances when compared with other techniques. The authors suggest sample sizes in the range of 220 to 440 units. Thus, at least 400 participants were planned to be collected as the samples.

\subsection{Measures}

The survey instrument consisted of 51 questions adapted and designed to gauge participants' attitude toward each of the constructs in the conceptual model. The demographic survey included participants' demographic information regarding gender, age, years of employment, job classification, education, number of employees, and age of the company. All questions were multiple-choice questions and the seven variables asked in the survey instrument with 5 Likert scale of items ranging from $1=$ strongly disagree to $5=$ strongly agree were: (1). Leadership Commitment was measured with 8 items was applied from Meyer \& Herscovitch, (2001), (2). Employers Branding was measured with 5 items, (3). Strategic Alignment was measure with 4 items, (4). Organizational Agility was measure with 5 items, Human Resource Practices was measure with 12 items that focused on the most commonly recognized area of HRM (e.g. selection, training, compensation, and appraisal), (6). Organizational Performance was measure with 4 items, and (7). Employee Engagement was measure with 6 items.

\subsection{Research Design}

Before administering the survey, pilot tests were carried out. In order to pre-test the questionnaires, HR managers of petrochemical organizations were identified from the list of Map Ta Phut Industrial Estate directory. After canvassing by telephone, $7 \mathrm{HR}$ managers, in a sub-set of the intended sample population, agreed to distribute the survey to 40 managers in their organization. The selected participants were contacted via email and provided with the questionnaires guaranteeing confidentiality. From the total of 40 managers from 7 organizations being surveyed, 32 returned their responses within 2 weeks. The response rate was $80 \%$. The 32 managers included 2 HR managers, 5 Administration managers, 4 Financial and accounting managers, 15 Operations managers, 2 Sales managers and 4 Maintenance managers. Once all of the surveys from pilot stage were completed, then total of 644 questionnaires with sealed envelope were delivered by the researcher to cooperating persons asked to forward the questionnaires to the respondents who were asked to return the questionnaires within 2 weeks. The final data collection process was conducted over a period of 3 months from the first week of May 2013 until the end of July 2013. In total, 457 questionnaires (equivalent to 71\%) were returned to the researcher. However, through data filtering, 62 questionnaires (14\%) were excluded although they were completed. The reason to delete these questionnaires is that the respondents provided the same answer for all of the questions.

\section{Results}

\subsection{Sample's Characteristic}

A total of 395 managers in 26 petrochemical companies in Rayong, Thailand, were completed survey with the response rate of $61 \%$. The respondents were classified into gender. A total of $263(66.58 \%)$ were males, while $132(33.42 \%)$ were females. And they also classified into five age categories. The age range of the respondents consisted of 38 (9.62\%) who were 30 years old or under, 88 (22.28\%) who were 31-35 years old, $94(23.80 \%)$ who were $36-40$ years old, 89 (22.53\%) who were $41-45$ years old, and $86(21.77 \%)$ who were 45 or older. The respondents were also classified into categories by the number of years they were employed with the company. The number of years the respondents were employed consisted of $5(1.27 \%)$ at less than 1 year, $52(13.16 \%)$ from 
1-3 years, 75 (18.99\%) from 4-6 years, $66(16.71 \%)$ from 7-10 years, and $197(49.87 \%)$ had 11 or more years. This information is summarized in Table 1.

Table 1. Descriptive statistics of demographic variables of the sample by gender, age, and years of employment

\begin{tabular}{lcc}
\multicolumn{1}{c}{ Characteristics } & Frequency & Percent \\
\hline Gender & 263 & 66.58 \\
Males & 132 & 33.42 \\
Females & & \\
Age & 38 & 9.62 \\
30 Years or under & 88 & 22.28 \\
$31-35$ Years & 94 & 23.80 \\
$36-40$ Years & 89 & 22.53 \\
$41-45$ Years & 86 & 21.77 \\
45 Years or older & & \\
Years of employment & 5 & 1.27 \\
Less than 1 Year & 52 & 13.16 \\
$1-3$ Years & 75 & 18.99 \\
$4-6$ Years & 66 & 16.71 \\
$7-10$ Years & 197 & 49.87 \\
11 or more Years & & \\
\hline
\end{tabular}

With regard to job classification, the respondents were classified into eight categories. Most of the subjects, 179 $(45.32 \%)$ were Operation Managers. The survey also indicated that $69(17.47 \%)$ were Finance and Accounting Managers, 51 (12.91\%) were Administrative Managers, 44 (11.14\%) were Human Resource Managers, 24 (6.28\%) were Procurement Managers, 13 (3.09\%) were Sales Managers, 9 (2.28\%) were Maintenance Managers, and 6 $(1.52 \%)$ were Planning Managers. According to their level of education, the respondents were classified into four education categories. The respondents were asked to identify the highest level of education they completed. The distribution consisted of 4 (1.01\%) below Bachelor Degree, 163 (41.27\%) Bachelor Degree, 224 (56.71\%) Master Degree and $4(1.01 \%)$ Doctoral Degree. The respondents were grouped into five groups according to the number of employees in the company. The number of employees showed the respondents as follows: $55(13.92 \%)$ had fewer than 500 employees, 61 (15.44\%) had 501-1000 employees, 25 (6.33\%) had 1,001-1500 employees, $6(1.52 \%)$ had 1501-2000 employees and 248(62.78\%) had 2001 or more. The respondents were also grouped into five categories dependent on the age of their companies. Regarding the age of their companies, respondents were employed by 20 $(5.06 \%)$ that were less than 5 years old, $62(15.70 \%)$ that were $5-10$ years old, $22(5.57 \%)$ that were $11-15$ years old, $46(11.65 \%)$ that were $16-20$ years old, and $245(62.03 \%)$ that were 21 years old or more. This information is summarized in Table 2.

Table 2. Descriptive statistics of demographic variables of the sample by job classification, education, number of employees and age of the company

\begin{tabular}{lcc}
\hline \multicolumn{1}{c}{ Characteristics } & Frequency & Percent \\
\hline Job Classification & & 11.14 \\
Human Resource Manager & 44 & 12.91 \\
Administrative Manager & 51 & 17.47 \\
Finance and Accounting Manager & 69 & 45.32 \\
Operation Manger & 179 & 3.09 \\
Sales Manager & 13 & 6.28 \\
Procurement Manager & 24 & 2.28 \\
Maintenance Manager & 9 & 1.52 \\
Planning Manger & 6 & \\
\hline
\end{tabular}




\begin{tabular}{lcc}
\hline Education & 4 & 1.01 \\
Below Bachelor Degree & 163 & 41.27 \\
Bachelor Degree & 224 & 56.71 \\
Master Degree & 4 & 1.01 \\
Doctoral Degree & & 13.92 \\
Number of employees & 55 & 15.44 \\
Fewer than 500 & 61 & 6.33 \\
$501-1,000$ & 25 & 1.52 \\
$1,001-1,500$ & 6 & 62.78 \\
$1,501-2,000$ & 248 & 5.06 \\
2,001 or More & & 15.70 \\
Age of the Company & 20 & 5.57 \\
Less than 5 Years & 62 & 11.65 \\
$5-10$ Years & 22 & 62.03 \\
$11-15$ Years & 46 & \\
$16-20$ Years & 245 & \\
21 Years or More & & \\
& & \\
\end{tabular}

\subsection{Statistics and Data Analysis}

The confirmatory Factor Analysis (CFA) is part of the SEM, which was used to assess the measurement model component of each hypothesized model, to establish the suitability of observed variables as indicators of latent variables, prior to testing the structural model component that examines the relationships between latent factors. The analysis results indicate how well the data fits the model and how the model can be adapted to improve the fit between the data and the model in subsequent steps. Principal axis factoring, with varimax rotation was used to measure the dimensionality of the risk attributes and also for better interpretability of factor loading. There were seven latent variables in this study: Leadership Commitment (LSC), Organizational Performance, and Employee Engagement (EYE), Employers Branding (EYB), Strategic Alignment (SGA), Organizational Agility (ONA), and Human Resource Practices (HRM). Thus, seven measurement models were revised based on an assessment of factor loading and a suggestion from modification indices.

Table 3 reports mean, standard deviation, alpha reliability, and inter-construct correlation. Construct reliability is evaluated using Cronbach's alpha. All of the measures exhibit acceptable levels of reliability with the minimum coefficient alpha at 0.87 . Compare among the seven latent variables of dimension, the correlation coefficients ranged between $0.022-0.218$ which is no high correlation magnitudes among latent variable. Collectively, these results provide evidence that it is appropriate to test the study hypotheses.

Table 3. Correlation coefficient among variables, standard deviation, mean, and reliability

\begin{tabular}{|c|c|c|c|c|c|c|c|c|c|}
\hline Variables & Alpha & Mean/SD & 1 & 2 & 3 & 4 & 5 & 6 & 7 \\
\hline LSC & 0.92 & $4.12, .42$ & 0.114 & & & & & & \\
\hline EYB & 0.88 & $4.09, .43$ & 0.032 & 0.173 & & & & & \\
\hline SGA & 0.87 & $3.91, .48$ & 0.045 & 0.058 & 0.136 & & & & \\
\hline ONA & 0.88 & $3.89, .50$ & 0.074 & 0.072 & 0.044 & 0.281 & & & \\
\hline HRM & 0.94 & $3.93, .41$ & 0.022 & 0.022 & 0.032 & 0.062 & 0.107 & & \\
\hline EYE & 0.90 & $3.99, .48$ & 0.051 & 0.021 & 0.029 & 0.052 & 0.050 & 0.201 & \\
\hline ONP & 0.88 & $3.90, .50$ & 0.039 & 0.019 & 0.027 & 0.049 & 0.058 & 0.091 & 0.300 \\
\hline
\end{tabular}




\subsection{Testing of Hypotheses}

The structural model was used to test the hypotheses of all seven factors tested in the measurement model. The scale for each factor was set by fixing the factor loading to one of its indicator variables and then applying the maximum likelihood estimation method. Inspection of initial model revealed that the all path were significant, expect one path parameter between Strategic Alignment and human resource practice was not significant. As suggested by Byrne (2009), discussion related to model fit has considered only the addition of parameters to the model. However, another side to the question of fit, particularly as it pertains to a full model, is the extent to which certain initially hypothesized paths may be irrelevant to the model. One way of determining such irrelevancy is to examine the statistical significance of all structural parameter estimates. In this study, one parameter that is nonsignificant; this parameter represent the path from SGA to HRM (HRM<---SGA; C.R. $=.825$ ). Specifically, there were no statistically significant relationship, $p$-value was 0.410 . Thus, this part needed to be deleted in the model. However, in the case of modification indexes for regression weight section, suggested factors into consideration, two additional paths were a candidate for addition to the model, and their associated expected parameter change (EPC). There were MI in reviewing statistic showed that the regression weights table of the modification indices indicate that a causal path is needed to be added from Strategic Alignment to Employers Branding (EYB <--- SGA), and expected value is estimated to be .359. The path following from Strategic Alignment to Organizational Agility (ONP <--- SGA), and expected value is estimated to be .303. The path following from Leadership Commitment (LSC) to Organizational Performance and expected value is estimated to be .359, and Leadership Commitment (LSC) to Employee Engagement and expected value is estimated to be .206 . These paths were added to the model.

The over fit of the final model is acceptable the standardized latent variable relationships estimated by $\chi 2=495.323, d f=197, p$-value $<=0.00, \chi 2 / d f=2.51$ and looking other indices as GFI $=0.90$ and, NFI $=0.91$, $\mathrm{TLI}=0.93$, RMR $=0.03$, and RMSEA $=.062$ were acceptable for modified model (see Figure 2). The results of the hypotheses tested on the estimated path were structuralized and based on the development of hypotheses, and it was used to evaluating of the research hypotheses.

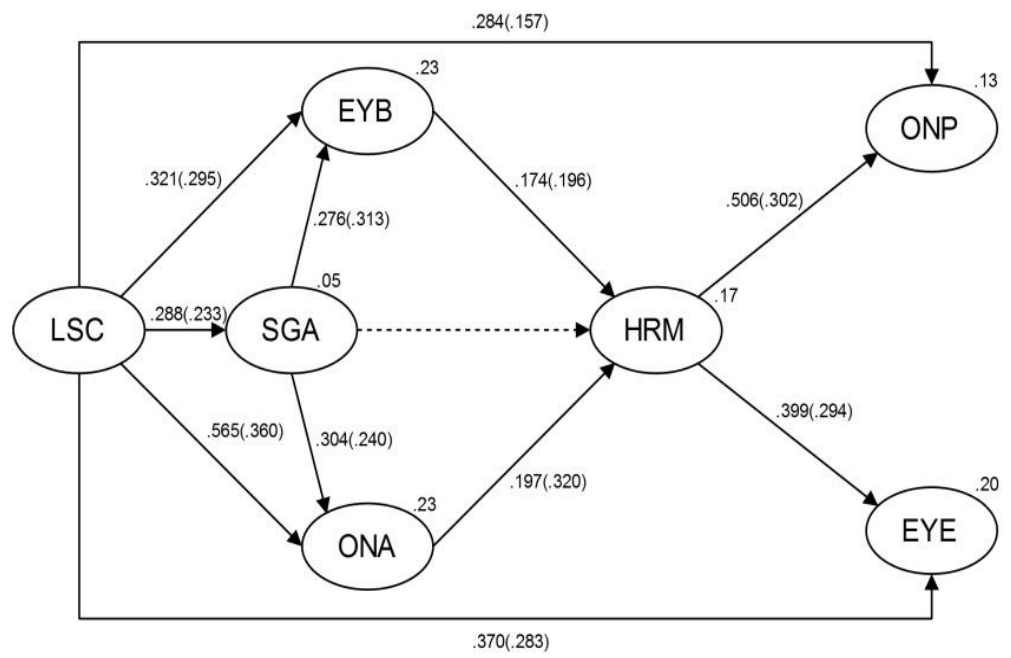

Figure 2. Structural final model

Note: unstandardized coefficients are listed first, standardized coefficients are in parentheses.

H1, H2 and H3 reveal that Leadership Commitment has a significant effect on Employers Branding, Strategic Alignment and Organizational Agility. The parameter of LSC on EYB, SGA, and ONA constructs was significant $\left(\mathrm{r}_{\mathrm{LSC}} * \mathrm{EYB}=.29, p\right.$-value $\left.=<0.001\right),\left(\mathrm{r}_{\mathrm{LSC} * \mathrm{SGA}}=.23\right.$, $p$-value $\left.=<0.001\right)$, and $\left(\mathrm{r}_{\mathrm{LSC} * \mathrm{ONA}}=.36, p\right.$-value $=$ $<0.001)$ respectively.

H4 and H6 show that Employers Branding and Organizational Agility has a significant effect on Human Resource Practice $\left(\mathrm{r}_{\text {EYB }} * \mathrm{HRM}=.20, p\right.$-value $\left.=<0.001\right),\left(\mathrm{r}_{\mathrm{ONA}}{ }^{* \mathrm{HRM}}=.32, p\right.$-value $\left.=<0.001\right)$, however, Strategic Alignment was not generate significant parameter to Human Resource Practice H5. However Strategic Alignment is significant indirect effect on Human Resource Practice via Employee Branding and Organizational 
Agility. The parameter of SGA on EYB was significant $\left(\mathrm{r}_{\mathrm{SGA} * \mathrm{EYB}}=.31, p\right.$-value $\left.=<0.001\right)$ and SGA on ONA was significant $\left(\mathrm{r}_{\mathrm{SGA} * \mathrm{ONA}}=.24, p\right.$-value $\left.=<0.001\right)$

H7 and H8 indicate that Human Resource Practices has a significant effect Organizational Performance and Employee Engagement. The parameter between the HRM and ONP constructs was significant $\left(\mathrm{r}{ }_{\text {HRM }}^{*}\right.$ ONP $=.30$, $p$-value $=<0.001)$ and $\left(\mathrm{r}_{\mathrm{HRM}}{ }^{\mathrm{EYE}}=.29, p\right.$-value $\left.=<0.001\right)$ for HRM and EYE. The results show that Leadership Commitment was significant effect on Organizational Performance and Employee Engagement $\left(\mathrm{r}_{\mathrm{LSC}^{*} \mathrm{ONP}}=.16\right.$, $p$-value $=<.0 .05)$, significant $\left(\mathrm{r}_{\mathrm{LSC}}{ }^{*} \mathrm{EYE}=.28, p\right.$-value $\left.=<0.001\right)$ for $\mathrm{H} 9$ and $\mathrm{H} 10$ respectively.

Table 4. Summary of correlation coefficients among dimensions

\begin{tabular}{cccccccc}
\hline \multicolumn{2}{c}{ Hypotheses Path } & Path Coefficient & S.E. & C.R. & $P$ & Result \\
\hline SGA & $<--$ & LSC & 0.233 & 0.075 & 3.843 & $* * *$ & Support \\
ONA & $<--$ & LSC & 0.360 & 0.092 & 6.133 & $* * *$ & Support \\
EYB & $<--$ & LSC & 0.295 & 0.066 & 4.847 & $* * *$ & Support \\
EYB & $<--$ & SGA & 0.313 & 0.051 & 5.398 & $* * *$ & Support \\
ONA & $<--$ & SGA & 0.240 & 0.067 & 4.545 & $* * *$ & Support \\
HRM & $<--$ & EYB & 0.196 & 0.051 & 3.425 & $* * *$ & Support \\
HRM & $<--$ & ONA & 0.320 & 0.035 & 5.654 & $* * *$ & Support \\
ONP & $<--$ & HRM & 0.302 & 0.091 & 5.559 & $* * *$ & Support \\
EYE & $<--$ & HRM & 0.294 & 0.08 & 4.975 & $* * *$ & Support \\
ONP & $<--$ & LSC & 0.157 & 0.086 & 2.936 & 0.003 & Support \\
EYE & $<--$ & LSC & 0.283 & 0.079 & 4.674 & $* * *$ & Support \\
\hline
\end{tabular}

Note: $* * *=$ Significant at $p \leq 0.001(t> \pm 3.29)$

C.R. $=t$-value

\subsection{Direct, Indirect and Total Effects}

Direct effects (see Figure 2) are the effects between two variables. Indirect effects are the effects between two variables mediated by other variables. Adding these two effects derives the total effect. This analysis gives another picture of the actual organizational relationships depicted in the model (see Table 4), it gives the standardized path coefficients of each practice effect on Organizational Performance and Employee Engagement. The results show that Leadership Commitment has a largest direct effect on Organizational Agility of 0.360 and smallest on direct effect on Organizational Performance. However, Leadership Commitment has direct effect on Employers Branding, on Employee Engagement and on Strategic Alignment -they were similar amount of 0.295, 0.283 and 0.233 respectively. In addition, the results show that Leadership Commitment has total effect, direct and indirect, on Organizational Agility of 0.416, on Employers Branding of 0.368, on Employee Engagement of 0.343, and also on Organizational Performance of 0.219. However, Leadership Commitment has indirect effect on Human Resource Practice of 0.205. According this, Employers Branding has a direct effect on Human Resource Practice of 0.196 and indirect effect on Employee Engagement and Organizational Performance of 0.058 and 0.059 respectively. With regard to Strategic Alignment has direct and indirect effect on Employers Branding and Organizational Agility of 0.313 and 0.240 respectively. However, it has indirect effect on Human Resource Practice, on Employee Engagement and on Organizational Performance of 0.138, 0.041 and 0.042 respectively. Organizational Agility has direct effect on Human Resource Practice of 0.320 and indirect effect on Employee Engagement and on Organizational Performance of 0.094 and 0.097 respectively. Refer to human resource practice has direct effect on Organizational Performance of 0.302 and on Employee Engagement of 0.294 .

\section{Discussion}

\subsection{Finding}

The findings of this study showed that Leadership Commitment affect Organizational Agility and also effect on Employers Branding. This finding was consistent with the prior studies by Vallaster \& Chernatony (2005), suggestion that leaders must thoroughly understand, support, and actively demonstrate commitment to the 
internal process. Employers branding process to be successful is not the office design that is relevant but employee knows what the commitment of leader stands for.

However, this finding reveals that Leadership Commitment affect Employee Engagement. This finding was consistent with prior study by Zhang et al., (2014) showed that leadership style is significantly related to the level of Employee Engagement. The finding of this study also showed that Leadership Commitment affect Organizational Performance. This finding consistent with Kieu (2010) found strong correlation between leadership and revenue growth, profits.

However, the results indicate that Leadership Commitment affect Strategic Alignment. This finding was consistent with the prior studies by Cascio et al., (2010), suggested that top management commitment has the stronger potential to enhance sales force automation adoption. In contrast, Strategic Alignment was not associated with human resource practice.

The study found that Employers Branding affect Human Resource Practices. This finding consistent with prior study by Kimpakorn \& Dimmitt (2007), which mention that leader/manager adopt a specific course of action to maximize performance to their practices mainly focus on traditional human resources management. The most important Employers Branding dimensions were human resources management (e.g. recruitment, compensation, training, reward, benefit package, recognition, performance evaluation and career advancement).

According to Strategic Alignment it did not direct affect Human Resource Practices. The result show that Strategic alignment it indirect affect Human resource Practices through Employer Branding and Organizational Agility. Therefore, organizations may be able to foster Employee Engagement through Strategic Alignment of their organizations (Stringer, 2007).

The finding of this study showed that Organizational Agility affect to human resource practice. This finding is similar with Dyer \& Shafer (1998), it suggest that Organizational Agility is fostered to the extent that the expanded use of fluid assignments is supported by employee communication, selection of employee (staffing), training and development, performance criteria, reward and recognition.

The study reveals that Human Resource Practices has an affect Organizational Performance and Employee Engagement. This finding was consistent with prior study by Moideenkutty et al., (2010), founded that human resource practice, highly selective staffing extensive training, performance management and empowerment are significant to organization performance. Thus, organizations that implement selective staffing, extensive training, and performance management practices are likely to have higher Organizational Performance.

In addition, the finding showed that Human Resource Practice affect to Employee Engagement. This finding coincide with (Vance, 2006; Dimba, 2010; Sardar et al., 2011) found that individuals who perceiving of recruitment, selection techniques, training, and pay for performance indicated the high level of engagement. Thus, recruitment, selection techniques, training and good reward system can be used to increase engagement of employee in organization.

\subsection{Conclusion}

The general understanding of this study informs practitioners that the effect of Leadership Commitment contributes directly to both Organizational Performance and also Employee Engagement. Yet, Leadership Commitment has a significant relationship to both Organizational Performance and Employee Engagement but Leadership Commitment has larger coefficient/impact to Employee Engagement than Organizational Performance. This result suggest that an increasing behavior of leader who commit to staying with company, working toward for organization's success of target, focus to achieving goal, and also working toward the success of organizational change, appears to influence the value of Organizational Performance as well as the level of Employee Engagement.

\section{References}

Alan M. S. (2006). Antecedents and consequences of employee engagement. Journal of Managerial Psychology, 21(7), 600-619. http://dx.doi.org/10.1108/02683940610690169

Amagoh, F. (2009). Leadership development and leadership effectiveness. Management Decision, 47(6), 989-999. http://dx.doi.org/10.1108/00251740910966695

Ambler, T., \& Barrow, S. (1996). The employer brand. The Journal of Brand Management, 4, 185-206. http://dx.doi.org/10.1057/bm.1996.42

Anitha J. (2014). Determinants of employee engagement and their impact on employee performance. International Journal of Productivity and Performance Management, 63(3), 308-323. 
http://dx.doi.org/10.1108/IJPPM-01-2013-0008

Babakus, E., Yavas, U., \& Karatepe, O. M. (2003). The effect of Management Commitment to Service Quality on employees' Affective and Performance Outcomes. Journal of the Academy of Marketing Science, 31(3), 272-286. http://dx.doi.org/10.1177/0092070303031003005

Backhaus, K., \& Tikoo, S. (2004). Conceptualizing and researching Employers Branding. Career Development International, 9(5), 501-517. http://dx.doi.org/10.1108/13620430410550754

Berthon, P., Ewing, M., \& Hah, L. L. (2005). Captivating company: Dimensions of Attractiveness in Employers Branding. International Journal of Advertising, 24(2), 151-172.

Block, L., \& Manning, L. (2007). A systemic approach to developing frontline leaders in healthcare. Leadership in Health Services, 20(2), 85-96. http://dx.doi.org/10.1108/17511870710745420

Blumberg, B., Cooper, D. R., \& Schindler, P. S. (2005). Business research methods. London, England: McGraw Hill Education.

Boswell, W. (2006). Aligning employees with the organization's strategic objectives: out of 'line of sight', out of mind. The International Journal of Human Resource Management, 17(19), 1489-1511. http://dx.doi.org/10.1080/09585190600878071

Byrne, B. (2009). Structural Equation Modeling with AMOS: Basic concepts, applications, and programming (2nd ed.). New York: Taylor and Francis.

Cascio, R., Mariadoss, B. J., \& Mouri, N. (2010). The impact of management commitment alignment on sales persons' adoption of sales force automation technologies: An Empirocal investigation. Industrial Marketing Management, 39(2010), 1088-1096.

Creswell, J. W. (2005). Educational research: Planning, conducting, and evaluating quantitative and qualitative research. Upper Saddle River, NJ: Pearson.

Delery, J. E., \& Doty, D. H. (1996). Modes of theorizing in strategic human resource management: tests of universalistic, contingency and configurational performance predictions. Academy of Management Journal, 39, 802-35. http://dx.doi.org/10.2307/256713

Dimba B. A. (2010). Strategic human resource management practices: effect on performance. Journal of Economic and Management studies, 1(2), 128-137. http://dx.doi.org/10.1108/20400701011073455

Ganon, M. A., \& Michael, J. H. (2003). Employee Strategic Alignment at a wood manufacturer; An exploratory analysis using lean manufacturing. Forest Products journal, 53(10), 24-29.

Garson, G. D. (1998; 2006). Structural Equation Modeling, Retrieved October 23, 2006 from http://www2.chass.ncsu.edu/garson/pa765/structur.htm

Hair, J. F., Black, W. C., Babin, B. J., Anderson, R. E., \& Tatham, R. L. (2006). Multivariate Data Analysis (6th ed.). New Jersey, Engle-Wood Cliffs: Pearson Prentice Hall.

Harter, J. K., Schmidt, F. L., \& Hayes, T. L. (2002). Business-unit-level relationship between employee satisfaction, Employee Engagement, and business outcomes: A meta-analysis. Journal of Applied Psychology, 87(2), 268-279. http://dx.doi.org/10.1037/0021-9010.87.2.268

Hu, L., \& Bentler, P. (1999). Cutoff criteria for fit indexes in covariance structure analysis: Conventional criteria versus new alternatives. Structural Equation Modeling, 6(1), 1-55.

Huselid, M. A. (1995). The Impact of Human Resource Management Practices on Turnover, Productivity, and Corporate Financial Performance. Academy of Management Journal, 38, 635-72. http://dx.doi.org/10.2307/256741

Kahn, W. A. (1990). Psychological conditions of personal engagement and disengagement at work. Academy of Management Journal, 33(4), 692-724. http://dx.doi.org/10.2307/256287

Kieu, H. Q. (2010). Leadership styles and Organizational Performance: A predictive Analysis (p. 219). University of Phoenix.

Kimpakorn, N., \& Dimmitt, N. (2007). Employers Branding: The perspective of hotel management in the Thai luxury hotel industry. Australasian Marketing Journal, 15(3), 49.

Kline, R. B. (2011). Principles and Practice of Structural Equation Modeling (3nd ed.), NewYork, NY: The Guilford Press. 
Kompaso, S. M., \& Sandhya, S. M. (2010). Employee engagement: The key to improving performance. International Journal of Business and Management, 5(12), 89.

Kristin, B., \& Surinder, T. (2004). Conceptualizing and researching Employers Branding. Career Development International, 9(4/5), 501-517. http://dx.doi.org/10.1108/13620430410550754

Lee Huey, Y., \& Kamarul, Z. B. A. (2009). The moderating effects of organizational culture on the relationships between leadership behaviour and organizational commitment and between organizational commitment and job satisfaction and performance. Leadership \& Organization Development Journal, 30(1), 53-86. http://dx.doi.org/10.1108/01437730910927106

Lory, A. M., \& Linda, J. M. (2007). A systemic approach to developing Frontline leaders in healthcare. Leadership in Health Services, 20(2), 85-96. http://dx.doi.org/10.1108/17511870710745420

Love, L. F., \& Signh, P. (2011). Workplace Branding: Leveraging Human Resources Management Practices for competitive Advantage Through "Best Employer" Survey. School of Human Resource Management, York University. http://dx.doi.org/10.1007/s10869-011-9226-5

Macey, W. H., Schneider, B., Barbera, K. M., \& Young, S. A. (2009). Employee Engagement: Tools for analysis, practice, and competitive advantage. Wiley-Blackwell, Malden, MA.

Martin, G., Beaumotn, P., Doig, R., \& Pate, J. (2005). Branding: A New PerformanceDiscourse for HR? European Management Journal, 23(1), 76-88. http://dx.doi.org/10.1016/j.emj.2004.12.011

May, D. R., Gilson, R. L., \& Harter, L. M. (2004). The psychological conditions of meaningfulness, safety and availability and the engagement of the human spirit at work. Journal of Occupational and Organizational Psychology, 77, 11-37. http://dx.doi.org/10.1348/096317904322915892

McCann, J., Selsky, J., \& Lee, J. (2009). Building agility, resilience and performance in turbulent environments. People and Strategy, 32(3), 44-51.

Meyer, J. P., \& Allen, N. J. (1991). A three- component conceptualization of organizational commitment. Human Resource Management Review, 1, 61-89. http://dx.doi.org/10.1016/1053-4822(91)90011-Z

Meyer, J. P., \& Herscovitch, L. (2001). Commitment in the workplace: Toward a general model. Human Resource Management Review, 11, 299-326. http://dx.doi.org/10.1016/S1053-4822(00)00053-X

Meyer, J. P., Stanley, J. D., Herscovitch, L., \& Topolnytsky, L. (2001). Affective, Continuance and Normative Commitment to the Organization: A meta-analysis of Antecedents, Correlates, and Consequences. Journal of Vocational Behavior, 61, 20-52. http://dx.doi.org/10.1006/jvbe.2001.1842

Moideenkutty, U., Al-Lamki, A., \& Murthy, S. R. Y. (2010). HRM practices and Organizational Performance in Oman. Personal Review, 40(2), 239-251. http://dx.doi.org/10.1108/00483481111106101

Robinson, D., Perryman, S., \& Hayday, S. (2004). The Drivers of Employee Engagement Report 408. Institute for Employment Studies, UK.

Sarabdeen, J., El-Rakhawy, N., \& KhanAli, N. H. (2011). Employers Branding in Selected Companies in United Arab Emirates. http://dx.doi.org/10.5171/2011.228533

Sardar, S., Rehman, A., Yousaf, U., \& Aijaz, A. (2011). Impact of HR Practices on Employee Engagement in Banking Sector of Pakistan. Interdisciplinary Journal of Contemporary Research in Business, 2(9), 378.

Schaufeli, W. B., \& Salanova, M. (2008). Enhancing work engagement through the management of human resources. In K. Näswall, J. Hellgren, \& M. Sverke (Eds.), The individual in the changing working life (pp. 380-402). New York: Cambridge University Press. http://dx.doi.org/10.1017/CBO9780511490064.018

Schumacker, R. E., \& Lomax, R. G. (1996). A beginner's guide to Structural Equation Modeling. Mahwah, NJ: Lawrence Erlbaum Associates.

Sharifi, H., \& Zhang, Z. (1999). A methodology for achieving agility in Manufacturing organizations. International Journal of Production Economics, 62(1-2), 7-22. http://dx.doi.org/10.1016/S0925-5273(98)00217-5

Sherehiy, B., Karwowski, W., \& Layer, J. K. (2007). A review of enterprise agility: concepts, frameworks, and attributes. Internal journal of Industrial Ergonomics, 37, 445-460. http://dx.doi.org/10.1016/j.ergon.2007.01.007

Shuck, M. B. (2010). Employee Engagement: An examination of antecedent and Outcome variables. Florida International University. http://dx.doi.org/10.1080/13678868.2011.601587 
Slack, J. F., Orife, N. J., \& Anderson, P. F. (2010). Effects of Commitment to Corporate Vision on Employee Satisfaction with their Organization: an Empirical Study in the United States. International Journal of Management, 27(3), 421.

Sowath, R., Alexandre, A., \& Oleksandr, T. (2014). A theoretical model of the antecedents and outcomes of employee engagement: Dubin's method. Journal of Workplace Learning, 26(3/4), 249-266. http://dx.doi.org/10.1108/JWL-09-2013-0063

Stringer, C. (2007). The relationship between Strategic Alignment, meaningful work, and Employee Engagement. The University of New Mexico.

Terpstra, D. E., \& Rozell, E. J. (1993). The relationship of staffing practices to organizational level measures of performance. Personnel Psychology, 46, 27-48. http://dx.doi.org/10.1111/j.1744-6570.1993.tb00866.x

Vallaster, C., \& de Chernatony, L. (2005). Internationalisation of services brands: The role of leadership during the internal brand building process. Journal of Marketing Management, 21, 181-203. http://dx.doi.org/10.1362/0267257053166839

Vance, R. J. (2006). Employee Engagement and Commitment SHRM Foundation. USA.

Wright, P. (1998). Introduction: Strategic human resource management research in the $21^{\text {st }}$ Century. Human Resource Management Review, 8(3), 178-191. http://dx.doi.org/10.1016/S1053-4822(98)90001-8

Wright, P., Gardner, T., Moynihan, L., \& Allen, M. (2005). The relationship between HR practices and firm performance: Examining causal order. Personnel Psychology, 58, 409-446. http://dx.doi.org/10.1111/j.1744-6570.2005.00487.x

Yauch, A. C. (2011). Measuring agility as a performance outcome. Journal of Manufacturing Technology Management, 22, 384-404. http://dx.doi.org/10.1108/17410381111112738

Youndt, M., Snell, S., Dean, J., \& Lepak, D. (1996). Human resource management, manufacturing strategy, and firm performance. Academy of Management Journal, 39, 836-866. http://dx.doi.org/10.2307/256714

Yusef, Y., Sarhadi, M., \& Gunasekaran, A. (1999). Agile manufacturing: the drives, concepts and attributes. International of production Economics, 62(1-2), 33-34. http://dx.doi.org /10.1016/S0925-5273(98)00219-9

Zhang, T., Avery, C. G., Bergsteiner, H., \& Mor, E. (2014). The relationship between leadership paradigms and employee engagement. Journal of Global Responsibility, 5(1). http://dx.doi.org/10.1108/JGR-02-2014-0006

\section{Copyrights}

Copyright for this article is retained by the author(s), with first publication rights granted to the journal.

This is an open-access article distributed under the terms and conditions of the Creative Commons Attribution license (http://creativecommons.org/licenses/by/3.0/). 